Original Article

\title{
PHYTOCHEMICAL, ANTI-INFLAMMATORY, ANTIOXIDANT, CYTOTOXIC AND ANTIBACTERIAL STUDY OF CAPPARIS CARTILAGINEA DECNEFROM YEMEN
}

\author{
BUSHRA ABDULKARIM MOHARRAM ${ }^{*}{ }^{1}$, HASSAN M. AL-MAHBASHI ${ }^{2}$, RIYADH SAIF-ALI ${ }^{3}$, FATEN ALI AQLAN ${ }^{1}$
}

${ }^{1}$ Department of Pharmacognosy, Faculty of Pharmacy, Sana'a University, Sana'a, Yemen, ${ }^{2}$ Department of Forensic Medicine and Clinical Toxicology, Faculty of Medicine, Sana`a University, Sanaa, Yemen, 3Department of Biochemistry and Molecular Biology, Faculty of Medicine, Sana'a University, Sana'a, Yemen Email: bushramoharam@yahoo.com

Received: 03 Oct 2017 Revised and Accepted: 27 Apr 2018

\section{ABSTRACT}

Objective: To investigate phytochemicals and biological activities of Capparis cartilaginea extracts.

Methods: The methanolic extracts of leaves, stem and twigs of $C$. cartilaginea were screened for their phytochemicals. The essential oil of the leaves was hydrodistilled by a Clevenger apparatus and analyzed by gas chromatography-mass spectrometry (GC-MS). The leaves extract of $C$. cartilaginea was evaluated for its anti-inflammatory effect, using formalin-induced paw edema. The leaves, stem and twigs extracts were assessed for their antioxidant activity, using free radical scavenging assay, cytotoxic activity, using 3-[4,5-dimethylthiazole-2-yl]-2,5-diphenyltetrazolium bromide (MTT) assay and antibacterial activity, using the microdilution method.

Results: All extracts of $C$. cartilaginea contained alkaloids, carbohydrates, protein, coumarin, phytosterols, bitter principles, phenols and tannins. The essential oil of the leaves was mainly composed of isopropyl isothiocyanate (69.4\%), butane,1-isothiocyanate (26.97\%) and isobutyl isothiocyanate $(3.26 \%)$. The leaves extract at doses of 200 and $400 \mathrm{mg} / \mathrm{kg}$, significantly inhibited paw edema at the $3^{\text {rd }} \mathrm{h}(49.1 \%, 54.0 \%$, respectively) and this effect was comparable to that of diclofenac (58.87\%). The leaves extract showed the highest antioxidant activity with $\mathrm{IC}_{50}$ value of $91.71 \mu \mathrm{g} / \mathrm{ml}$. The twigs extract exhibited the highest cytotoxic activity against human lung carcinoma (A549) with IC 50 of $57.5 \mu \mathrm{g} / \mathrm{ml}$. The leaves and stem extracts exhibited antibacterial activity against Staphylococcus aureus with minimum inhibitory concentration (MIC) of $5.0 \mathrm{mg} / \mathrm{ml}$.

Conclusion: The leaves extract of $C$. cartilaginea is a potential source of bioactive compounds that could have a role in anti-inflammation. Twigs extract of the $C$. cartilaginea possesses a potential cytotoxic effect on human lung cell line.

Keywords: Capparis cartilaginea, Phytochemical, Essential oil, Anti-inflammation, Antioxidant cytotoxicity, Antibacterial

(C) 2018 The Authors. Published by Innovare Academic Sciences Pvt Ltd. This is an open access article under the CC BY license (http://creativecommons.org/licenses/by/4.0/) DOI: http://dx.doi.org/10.22159/ijpps.2018v10i6.22905

\section{INTRODUCTION}

Capparis are the largest genera of Capparidaceae which are shrubs, trees and woody climbers that comprise about 250-400 species. They are found in tropical and subtropical zones of Southern America, Europe, Africa, Madagascar, Asia, Australia, and the Pacific Islands [1]. In Yemen, four species were found, Capparis cartilaginea Decne, C. spinosa, C. deciduas and C. tomentosa [2].

Capparis cartilaginea have various traditional uses in the Arab region. It is used for easing bruises, childbirth, earache, headache, paralysis, swelling, skin and joint inflammation, knee problems; tendinitis and snakebites [3, 4]. In Yemen, it is called lattssaf, lașaf or nişaf [4] and used to treat itching, shortness of breath, head cold, tumors, wounds, boil and for painful knees [5-7]. Phytochemical studies of $C$. cartilaginea have resulted in isolating flavonoids $[8,9]$ and isothiocyanates [3]. Other phytochemicals, such as carbohydrates, saponins, polyphenols, flavonoids, tannins, triterpenes, sterols, amino acid and protein have also been found in the leaves of $C$. cartilaginea from Yemen [10].

A previous investigation has reported that Capparis species extracts, such as C. spinosa and C. decidua from Saudi Arabia has a significant antiinflammatory activity [11]. Recently, the mechanism of antiinflammatory effect of $C$. spinosa was suggested by El Azhary et al. [12] and involved inhibition of cellular infiltration and cytokine gene expression. Rutin, a flavonoid, obtained from C. acutifolia Sweet exhibited a potent anti-inflammatory effect [13]. Other studies have reported the antioxidant, cytotoxic, larvicidal, antimicrobial, hypotensive and bradycardiac activities of $C$. cartilaginea $[3,9,10,14-19]$.

Although previous studies have reported the phytochemical screening of Yemeni $C$. cartilaginea leaves from various places $[9,10]$, in this study, the essential oil component, acute toxicity and anti-inflammatory effects of $C$. cartilaginea leaves extract were determined; which, to the best of our knowledge have never been investigated. Taking into account the environmental effects on the quality and quantity of chemical components of plant species and the consequent difference in biological effects, our study investigated the phytochemical screening of leaves, stem and twigs of $C$. cartilaginea and their biological activities, including the antibacterial, antioxidant and cytotoxic activities.

\section{MATERIALS AND METHODS}

\section{Chemicals, reagents and drugs}

Solvents used in plant extraction and chemical tests, including methanol (99.8\%), diethyl ether, toluene, dimethylsulfoxide (DMSO) (Scharlae, Spain), $10 \%$ ammonia solution, glacial acetic acid (WinLab, UK), ethyl acetate (HiMedia, India), formic acid (Fluka, Switzerland), chloroform (Sigma, Germany), anhydrous sodium sulphate, n-hexane (Univar, USA)and tween 80 (Uni-Chem, Beograd). Formalin was obtained from BDH Chemicals, UK. Reagents, including 2,2-diphenyl-1-picrylhydrazyl (DPPH) and 3-[4,5-dimethylthiazole-2-yl]-2,5-diphenyltetrazolium bromide (MTT) were purchased from Sigma Aldrich, Germany. The standard drug such as diclofenac sodium was purchased from Denk Pharma, Germany. Vitamin C was purchased from Sigma, USA. Ceftriaxone (Ceftix-3®) was obtained from Trifecta pharma, China. Amikacin (likacin $₫$ ) was purchased from Lisapharma, Italy. All the chemicals and solvents used were of standard analytical grades.

\section{Plant material}

The plant C. cartilaginea Decne was collected from AL-Madan, Emran province, Yemen in November 2016. The plants were identified by Dr. Abdul Wali Al Khulaidi, Public Authority for 
Research and Agricultural Extension, Dhamar, Yemen. A voucher specimen (CCD 16) was prepared and deposited in the Pharmacognosy Department, Faculty of Pharmacy, Sana'a University.

\section{Preparation of the methanol extracts}

The leaves (2827.51 g), twigs (1188.26 g) and stem (464.88 g) of the plant were cleaned, air-dried in the shade and then grounded. The parts were extracted with methanol and filtered. The filtrates were dried using a rotary evaporator. The final percentage yield of leaves, twigs and stem was then calculated. Subsequently, the extracts were stored in airtight containers at room temperature until use.

\section{Experimental animals}

Mature male Albino rats, weighing 150-250 g, were obtained from the animal house of Faculty of Science, Sana'a University. The rats were used for determination of acute oral toxicity, median lethal dose $\left(L_{50}\right)$ and anti-inflammatory activity. The animals were housed in polypropylene cages under controlled temperature $(23 \pm 2$ ${ }^{\circ} \mathrm{C}$ ) and light (light-dark cycle of $12 \mathrm{~h}$ ). They were fed with food and water ad libitum. The rats were acclimatized in the laboratory at least $48 \mathrm{~h}$ before the experiments. The experiments were approved by the Institutional Ethical Committee, Faculty of Medicine and Health Sciences, Sana`a University, (01/FPh Sana'a/2016).

\section{Phytochemical screening}

\section{Chemical tests}

Chemical tests were performed according to Banu and Cathrine [20] to identify alkaloids, carbohydrates, fixed oils and fats, glycosides, anthraquinones, phenolic compounds and tannins, phytosterols, proteins, saponins and gum and mucilage.

\section{Thin layer chromatography}

Components of the extracts and their retention factor (Rf) values of each part of $C$. cartilaginea were identified using thin layer chromatography (TLC) using a conventional one-dimensional ascending method using silica gel 60 F254, 20 x $20 \mathrm{~cm}$ (Merck, Germany) [21]. Each of the three extracts (1 g) was individually dissolved in $5 \mathrm{ml}$ of methanol on a water bath for $10 \mathrm{~min}$. To extract alkaloids, the methanol extracts $(\mathrm{lg})$ were moistened with $1 \mathrm{ml}$ of $10 \%$ ammonia solution and then $5 \mathrm{ml}$ of methanol was added and the alkaloids were then extracted for $10 \mathrm{~min}$ on a water bath. Each extract solution was spotted for TLC analyses.

Different solvent systems were used to identify the components of the extracts of the plant. Solvent system I; ethyl acetate: methanol: water (100:13.5:10) was used for the analysis of polar compounds, including anthraglycosides, alkaloids, cardiac glycosides, bitter principles, and flavonoids. The solvents were allowed to run for a distance of $6 \mathrm{~cm}$. Solvent system II; ethyl acetate: formic acid: glacial acetic acid: water (100:11:11:26) was used for flavonoids identification. Solvent system III; chloroform: glacial acetic acid: methanol: water (64:32:12:8) was used for saponins. Solvent system IV; diethyl ether: toluene (1:1) saturated with $10 \%$ acetic acid was used for coumarins. The developed chromatograms were first inspected under UV light (VilberLourmat, French) at wavelengths of $254 \mathrm{~nm}$ and $365 \mathrm{~nm}$. Each chromatogram was then analyzed for the presence of bioactive constituents by spraying with appropriate reagents.

\section{Isolation of essential oil}

The dried leaves of C. cartilaginea Decne (317.4 g) were hydrodistilled for $6 \mathrm{~h}$ using a Clevenger apparatus. The oily layer was measured, collected and dried, over anhydrous sodium sulphate. The percentage of yield was also calculateded. The oil was placed in a vial and kept in a cool place until used.

\section{Gas chromatographic-mass spectroscopy analysis (GCMS)}

The composition of the essential oil of the plant was determined using a Shimadzu GCMS-QP2010 SE System operating in EL mole (70Ev), equipped with a flamed ionizing detector (FID), and aRTx-5 (30 $\mathrm{m} \times 0.25 \mathrm{~mm}, 0.25 \mu \mathrm{m}$ film thickness), capillary column. One drop of oil was dissolved in 5-6 drops of n-hexane and placed in the specific vial used for GC analysis. The diluted sample $(1 \mu \mathrm{l})$ was injected automatically in spilt mode (auto-injector Shimadzu AOC$20 \mathrm{i}$ ), using pressure-controlled nitrogen as a carrier gas at a linear velocity of $42.9 \mathrm{~cm}^{3} / \mathrm{s}$.

The temperature of the injector and detector was maintained at 250 ${ }^{\circ} \mathrm{C}$. The oven temperature was programed at $45^{\circ} \mathrm{C}$ for $2 \mathrm{~min}$ and gradually increased to $300{ }^{\circ} \mathrm{C}$ at a rate of $5{ }^{\circ} \mathrm{C} / \mathrm{min}$ and held for 5 min. The peak areas and retention times were measured via computerized integration. The relative amounts of the individual components were calculated based on the peak area obtained without a flame ionization detector (FID) response factor correction. A homologous series of $\mathrm{n}$-alkane standards $\left({ }_{28} \mathrm{C}-{ }_{8} \mathrm{C}\right)$ was also prepared and analyzed under the same conditions used for essential oils. The constituents of essential oil were determined by comparing their relative retention indices with those in the literature and their mass spectral data with the existing Wiley library [22].

\section{Acute oral toxicity}

Acute oral toxicity and $\mathrm{LD}_{50}$ of the methanolic extract of $C$. cartilaginea Decne leaves were determined in albino rats as described in Al-Mahbashi et al. [23]. In a pilot experiment, five groups (six rats each) received the leaves extract dissolved in distilled water with $3 \%$ tween 80 at doses of 500, 1000, 2000, 3000 and $5000 \mathrm{mg} / \mathrm{kg}$ body weight (b. w), respectively. Signs of toxicity and number of deaths per dose in the following $48 \mathrm{~h}$ were also recorded.

\section{Anti-inflammatory assay}

To determine the anti-inflammatory effect of the dried leaves extract in the rat, a formalin-induced inflammation test was carried out as described by Hosseinzadeh and Younesi [24] and Shripad et al. [25].

\section{Formalin-induced inflammation}

Rats were divided into four groups of 6 and food was held overnight before the day of the experiment. Treatment groups received 200 and $400 \mathrm{mg} / \mathrm{kg}$ orally (P. O.) of the extract. The reference group received oral diclofenac sodium $20 \mathrm{mg} / \mathrm{kg}$, while the control group were given only distilled water in $3 \%$ tween $80(2 \mathrm{ml} / \mathrm{kg})$, orally. Treatment of rats was 1 hour before administration of inflammatory agent. The acute inflammation was induced by intraplantar administration of $0.1 \mathrm{ml}$ of $2 \%$ freshly prepared formalin solution into the right hind paw of each rat in each group. Paw size of rats was measured prior to administration of the inflammatory agent. The changes in paw size were measured using a plethysmometer to every $1 \mathrm{~h}$ for the following $4 \mathrm{~h}$. Edema was assessed in terms of the difference in the zero-time linear diameter of the injected hind paw and its linear diameter at time t (i.e. 1, 2, 3, 4 h) following the administration of $2 \%$ formalin solution.

The anti-inflammatory effect of the extract was calculated using the following equation:

$$
\text { Inhibition }(\%)=\frac{\mathrm{Ec}-\mathrm{Et}}{\mathrm{Ec}} \times 100
$$

$\mathrm{Ec}=$ represents the average difference in paw size of the control group.

$\mathrm{Et}=$ the average difference in paw size after the extract was administered to the rats.

\section{Antioxidant activity}

The antioxidant activity of $C$. cartilaginea Decne extracts was carried out according to the method described by Blois [26] and Bains and Tripathi [27] with a few modifications. The stock solution of each extract $(10 \mathrm{mg} / \mathrm{ml})$ was diluted into 6 concentrations $(2000,1000$, $500,250,125$ and $62.5 \mu \mathrm{g} / \mathrm{ml})$ in methanol. An aliquot $(100 \mu \mathrm{l})$ of the extract was placed in a microtiter plate before $100 \mu \mathrm{l}$ of DPPH solution ( $0.1 \mathrm{mmol})$ was added to each well to get a serial concentration of $1000,500,250,125,62.5$ and $31.25 \mu \mathrm{g} / \mathrm{ml}$. The mixture was shaken vigorously for $1 \mathrm{~min}$ and allowed to stand at room temperature for $30 \mathrm{~min}$. The reduction of the DPPH free radical was measured by reading the absorbance at $492 \mathrm{~nm}$ using spectrophotometer (microplate reader) (LiNEAR GEA, Spain). Vitamin C (100-3.125 $\mu \mathrm{g} / \mathrm{ml})$ was used as a positive control and the 
methanol solvent as a negative control. Extracts without DPPH were also used as blank solutions. Each experiment was carried out in triplicates. The percentage of inhibition was calculated using the following equation:

$$
\% \text { inhibition }=\frac{\mathrm{Abc}-(\mathrm{Ab} 1-\mathrm{Ab} 0)}{\mathrm{Abc}} \times 100
$$

$\mathrm{Abc}=$ absorbance of DPPH, Ab1 = absorbance of extract with DPPH and $\mathrm{Ab0}=$ absorbance of extracts without DPPH (sample blank).

\section{Cytotoxic activity}

\section{Cell culture}

Human breast adenocarcinoma cell line (MCF-7), human lung cancer cell line (A-549) and human colon adenocarcinoma (HCT-116), were originally purchased from the American type culture collection (ATCC, Wesel, Germany) and grown in the tissue culture lab of the Egyptian company for production of vaccines, sera and drugs (Vacsera, Giza, Egypt). The cells were maintained in Roswell Park Memorial Institute medium (RPMI1640) in a humidified, 5\% (v/v) $\mathrm{CO}_{2}$ atmosphere at $37^{\circ} \mathrm{C}$.

\section{Cytotoxicity assay}

Exponentially growing cells were trypsinized, counted and seeded at appropriate densities (5000 cells/0.33 $\mathrm{cm}^{2}$ well) into 96 -well microtiter plates. Cells were incubated in a humidified atmosphere at $37{ }^{\circ} \mathrm{C}$ for $24 \mathrm{~h}$. Then, cells were exposed to different extracts at the desired concentrations, $(0.1,1,10,100$ and $1000 \mu \mathrm{g} / \mathrm{ml})$ for 72 $\mathrm{h}$. At the end of the treatment period, the media was removed and cells were incubated with $200 \mu \mathrm{l}$ of $5 \%$ MTT solution/well to allow to metabolize the dye into a coloured-insoluble formazan complex for $2 \mathrm{~h}$. The medium was discarded from the wells and the formazan crystals were dissolved in $200 \mu \mathrm{l} /$ well-acidified isopropanol for $30 \mathrm{~min}$, covered with aluminium foil and with continuous shaking using a MaxQ 2000 plate shaker (Thermo Fisher Scientific Inc., MI) at room temperature. Absorbance was measured at $570 \mathrm{~nm}$ using an Epoch microplate reader (BioTek instruments, Winooski VT). The cell viability was expressed relative to the untreated control cells and the concentrations induced $50 \%$ growth inhibition ( $\mathrm{IC}_{50}$ ) were calculated from the concentration-response curve using GraphPad prism 5 Software (GraphPad Software, Inc., CA, USA) [28, 29].

\section{Antibacterial activity}

The methanol extracts of leaves, stem and twigs and essential oil of C. cartilaginea Decne were tested against Staphylococcus aureus, Pseudomonas aeruginosa and Escherichia coli using broth microdilution method. All bacteria under investigation were subcultured on human blood agar (HuBA) (Rapid laps, UK). The bacteria used were obtained from the Microbiology department of YemenLab, Sana'a, Yemen.

\section{Preparation of bacterial suspensions}

Bacterial suspensions were prepared according to standard methods recommended by the National Committee for Clinical Laboratory Standard [30] with minor modifications. The bacterial cultures were grown on HuBA at $35^{\circ} \mathrm{C}$ for $24 \mathrm{~h}$. About 4-5 isolated bacteria colonies were transferred into a sterile screw cap bottle containing $5 \mathrm{ml}$ of sterile normal saline. The suspension was mixed and the turbidity was standardized to $2-5 \times 10^{8}$ colony forming units $/ \mathrm{ml}(\mathrm{CFU} / \mathrm{ml})$, that match the turbidity of McFarland 0.5 standard at $530 \mathrm{~nm}$. The resulting bacterial suspension $\left(2-5 \times 10^{8}\right.$ $\mathrm{CFU} / \mathrm{ml}$ ) was diluted in Mueller-Hinton broth (MHB) (Oxoid, UK) to obtain the test inoculum of $2-5 \times 10^{4} \mathrm{CFU} / \mathrm{ml}$.

\section{Broth microdilution assay}

The quantitative assay of the antibacterial activity of the plant extracts was performed according to the reference method recommended by [30]. Sterility condition was maintained throughout the experiments. The stock solution $(500 \mathrm{mg} / \mathrm{ml})$ of each extract was dissolved in 1\% DMSO: methanol $(1: 1)$ and serially diluted in MHB into 6 serial concentrations $(10-0.31 \mathrm{mg} / \mathrm{ml})$. Aliquots $(100 \mu \mathrm{l})$ of each resultant solution were then transferred into 96-well microtiter plates. Each well was later filled with $100 \mu \mathrm{l}$ of the bacterial suspension $\left(2-5 \times 10^{4} \mathrm{CFU} / \mathrm{ml}\right)$, which achieved the desired final concentrations of the test material $5,2.5,1.25,0.63$ 0.31 and $0.16 \mathrm{mg} / \mathrm{ml}$.

Five controls were used; negative control [DMSO: methanol (1:1), growth control $(100 \mu \mathrm{l}$ of bacterial suspension was mixed with 100 $\mu \mathrm{l}$ of MHB), positive control (Ceftriaxone was used for P. aeruginosa and E. coli while Amikacin was used for S. aureus), sterile control of plant extracts $(100 \mu \mathrm{l}$ of plant extracts and $100 \mu \mathrm{l}$ MHB broth) and sterile broth $200 \mu \mathrm{l}$ of MHB broth alone was used to confirm the sterility of the broth. The microtiter plates were incubated for $24 \mathrm{~h}$ at $35{ }^{\circ} \mathrm{C}$. The MIC value was recorded as the mean concentration of triplicates. The antibacterial activity was categorized as strong if MIC was less than $1.00 \mathrm{mg} / \mathrm{ml}$, moderate if MIC was between 1.00 and $4.9 \mathrm{mg} / \mathrm{ml}$ and weak if MIC was more than $5.00 \mathrm{mg} / \mathrm{ml}$ [31].

\section{Statistical analysis}

Results were expressed as mean \pm Standard deviation (SD) of the three triplicates. The data were analyzed using Statistically Package for Social Sciences (SPSS) version 11.5. Categorical variables were represented by frequencies and percentages. The paired T-test was used to test the significance of the differences between each two groups. The significance level was set at 0.05 .

\section{RESULTS}

\section{Phytochemical screening and thin layer chromatography}

The chemical tests used for identifying the active constituents showed the presence of various bioactive components. Compounds, such as alkaloids, carbohydrates, phytosterol, phenolic compounds and tannins, were found in the leaves, twigs and stem of $C$. cartilaginea. However, fixed oils, fats and glycosides were found only in the leaves and stem extracts. The TLC showed one spot of alkaloid in each extract (table 1). A number of spots corresponding to the bitter principles in the leaves and stems extracts were higher than that of those of the twig extract. Phenolic compounds, such as flavonoids and coumarins were found in the three extracts, however, saponins and anthraglycosides were absent. The solvent systems, the Rf values and the identified active constituents for each extract are summarized in table 1.

\section{Essential oil}

C. cartilaginea leaves yielded a final $0.35 \%$ pale yellowish oil. Table 2 shows the percentage of each component in the essential oil of $C$. cartilaginea (the components are arranged in order of elution on RTx-5 column). Three compounds were identified in the leaves of $C$. cartilaginea representing $99.64 \%$ of the oil. The oil composed mainly of isopropyl isothiocyanate (69.41\%), butane, 1isothiocyanate $(26.97 \%)$ and isobutyl isothiocyanate $(3.26 \%)$.

\section{Acute toxicity}

The examined doses $(500,1000,2000,3000$, and $5000 \mathrm{mg} / \mathrm{kg}$ b.w.) of C. cartilaginea did not produce any notable acute toxic effects. No diarrhea, hematuria, restlessness, uncoordinated muscle movements, respiratory distress or death in all groups of rats during $48 \mathrm{~h}$.

\section{Anti-inflammatory activity}

The leaves extract at a dose of 200 and $400 \mathrm{mg} / \mathrm{kg}$ significantly $(\mathrm{p}=$ 0.004 and 007 , respectively) inhibited paw edema at the $3^{\text {rd }} \mathrm{h}$ following inflammation induction compared with the control animals which received distilled water with percentage inhibition of $49.14 \%$ and $54.03 \%$, respectively (table 3 ). This effect was similar to the effect induced by diclofenac sodium (positive control) $20 \mathrm{mg} / \mathrm{kg}$ (58.87\%). There was no significant difference between the two doses $(200$ and $400 \mathrm{mg} / \mathrm{kg}$ ) of the extracts and diclofenac.

\section{The antioxidant activity}

All extracts showed antioxidant activities except the essential oil. The highest activity was obtained from the leaves with $\mathrm{IC}_{50}$ value of $91.8 \mu \mathrm{g} / \mathrm{ml}$ followed by the twigs and stem extracts with $\mathrm{IC}_{50}$ values of 502 and $584 \mu \mathrm{g} / \mathrm{ml}$, respectively (fig. 1). 
Table 1: TLC investigation of methanol extracts of a different part of Cappariscartilaginea

\begin{tabular}{|c|c|c|c|c|c|}
\hline No. & Constituent & Solvent system & Part & No. spots & Rf values \\
\hline \multirow[t]{3}{*}{1} & Anthraglycoside & EtOAc: MeOH: water & Leaves & - & - \\
\hline & & $(100: 13.5: 10)$ & Stem & - & - \\
\hline & & & Twig & - & - \\
\hline \multirow[t]{11}{*}{2} & Bitter principles & EtOAc: $\mathrm{MeOH}$ : water & Leaves & 4 & 0.11 \\
\hline & & $(100: 13.5: 10)$ & & & 0.16 \\
\hline & & & & & 0.43 \\
\hline & & & & & 0.58 \\
\hline & & & Stem & 5 & 0.08 \\
\hline & & & & & 0.28 \\
\hline & & & & & 0.43 \\
\hline & & & & & 0.45 \\
\hline & & & & & 0.54 \\
\hline & & & Twig & 2 & 0.11 \\
\hline & & & & & 0.15 \\
\hline \multirow[t]{3}{*}{3} & Alkaloid & EtOAc: $\mathrm{MeOH}$ : water & Leaves & 1 & 0.02 \\
\hline & & $(100: 13.5: 10)$ & Stem & 1 & 0.03 \\
\hline & & & Twig & 1 & 0.05 \\
\hline \multirow[t]{5}{*}{4} & Flavonoid & EtOAc: formic a.: glacial acetic a.: & Leaves & 2 & 0.22 \\
\hline & & water (100:11:11:26) & & & 0.3 \\
\hline & & & Stem & 2 & 0.22 \\
\hline & & & & & 0.3 \\
\hline & & & Twig & 1 & 0.3 \\
\hline \multirow[t]{3}{*}{5} & Saponins & $\mathrm{CHCl}_{3}$ :glacial acetic a.: $\mathrm{MeOH}$ : water & Leaves & - & - \\
\hline & & $(64: 32: 12: 8)$ & Stem & - & - \\
\hline & & & Twig & - & - \\
\hline \multirow[t]{9}{*}{6} & Coumarins & Diethyl ether: toluene (1:1) & Leaves & 3 & 0.15 \\
\hline & & & & & 0.24 \\
\hline & & & & & 0.3 \\
\hline & & & Stem & 3 & 0.15 \\
\hline & & & & & 0.24 \\
\hline & & & & & 0.3 \\
\hline & & & Twigs & 3 & 0.15 \\
\hline & & & & & 0.24 \\
\hline & & & & & 0.3 \\
\hline
\end{tabular}

Where, TLC-thin layer chromatography, EtOAc-ethyl acetate, $\mathrm{MeOH}$-methanol, $\mathrm{CHCl}_{3}$-chloroform, a.-acid, Rf-retention factor,--absent

Table 2: Percentage composition of the leaves oil of capparis cartilaginea on RTx-5 column

\begin{tabular}{|c|c|c|c|c|c|}
\hline \multirow[t]{2}{*}{ NO. } & \multirow[t]{2}{*}{ Components } & \multicolumn{4}{|l|}{ Retention indices } \\
\hline & & *Percentage (\%) & $\mathbf{R I}_{\mathbf{x}}$ & RI[32] & ID methods \\
\hline 1 & Isopropyl isothiocyanate & 69.41 & 833 & 837 & i, ii \\
\hline 2 & Butane,1-isothiocyanate & 26.97 & 928 & 920 & i, ii \\
\hline \multirow[t]{2}{*}{3} & Isobutyl isothiocyanate & 3.26 & 949 & - & ii \\
\hline & Total & 99.64 & & & \\
\hline
\end{tabular}

*Percentage were expressed as peak area normalization on column RTx-5 without correction factor. ID methods-identification methods, i-retention index, ii-mass spectrum. RIx-retention index measured relative to n-alkanes on Rtx-5 column, RI-retention index on a DB-5 column obtained in literature.

Table 3: Effect of the oral doses $(200 \mathrm{mg} / \mathrm{kg}$ and $400 \mathrm{mg} / \mathrm{kg})$ of Capparis cartilaginea leaves extract and diclofenac on formalin-induced paw edema in rat

\begin{tabular}{|c|c|c|c|c|}
\hline \multirow[t]{2}{*}{ Time (h) } & \multirow[t]{2}{*}{ Distilled $\mathrm{H}_{2} \mathrm{O}$} & \multicolumn{2}{|c|}{ Extract (mg/kg) } & \multirow[t]{2}{*}{ Diclofenac (20 mg/kg) } \\
\hline & & 200 & 400 & \\
\hline 0 & $3.58 \pm 0.2$ & $3.58 \pm 0.2$ & $3.75 \pm 0.3$ & $4.02 \pm 0.04$ \\
\hline 1 & $5.08 \pm 0.2$ & $\begin{array}{l}4.92 \pm 0.5 \\
(11.11)\end{array}$ & $\begin{array}{l}5.00 \pm 0.4 \\
(20.0)\end{array}$ & $\begin{array}{l}5.27 \pm 0.4 \\
(16.67)\end{array}$ \\
\hline 2 & $5.58 \pm 0.5$ & $\begin{array}{l}5.00 \pm 0.3 \\
(29.17)\end{array}$ & $\begin{array}{l}5.08 \pm 1.5 \\
(33.33)\end{array}$ & $\begin{array}{l}5.15 \pm 0.3 \\
(43.33)\end{array}$ \\
\hline 3 & $5.65 \pm 0.05$ & $\begin{array}{l}4.63 \pm 0.4^{*} \\
(49.14)\end{array}$ & $\begin{array}{l}4.70 \pm 1.4^{*} \\
(54.03)\end{array}$ & $\begin{array}{l}4.87 \pm 0.2^{*} \\
(58.87)\end{array}$ \\
\hline 4 & $5.03 \pm 0.7$ & $\begin{array}{l}4.42 \pm 0.4 \\
(42.53)\end{array}$ & $\begin{array}{l}4.40 \pm 0.3 \\
(55.17)\end{array}$ & $\begin{array}{l}4.73 \pm 0.2 \\
(50.57)\end{array}$ \\
\hline
\end{tabular}

Values are expressed as mean $\pm \mathrm{SD}, \mathrm{n}=6,{ }^{*} \mathrm{P}<0.01$ when compare samples with the control group (Distilled $\mathrm{H}_{2} \mathrm{O}$ ), the Percentage inhibition of the formalin-induced inflammation (edema) produced by test extract and Diclofenac are indicated in parenthesis. 


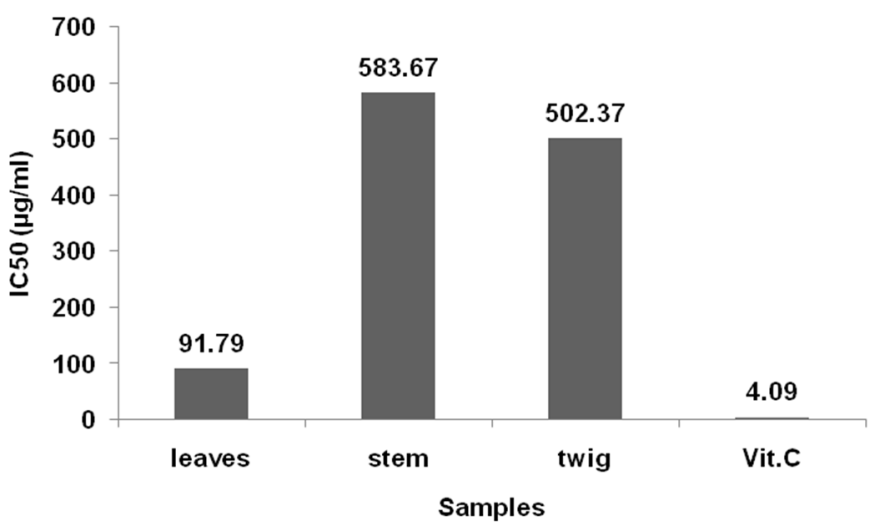

Fig. 1: $\mathrm{IC}_{50}$ values $(\mu \mathrm{g} / \mathrm{ml})$ of the methanol extracts of leaves, stem and twigs of Capparis cartilaginea and vitamin C (vit. C)

Table 4: IC ${ }_{50}$ values $(\mu \mathrm{g} / \mathrm{ml})$ for cell growth inhibition of the methanol extracts of Capparis cartilaginea against MCF-7, A-549 and HTC-116 cell lines

\begin{tabular}{llll}
\hline Samples & MCF-7 & A-549 & HTC-116 \\
\hline Leaves & 602.5 & $>1000$ & $>1000$ \\
Stem & 407 & 240 & 871 \\
Twig & 380 & 57.5 & 656 \\
Doxorubicin & 1.2 & 0.9 & 1.24 \\
\hline
\end{tabular}

Where, MCF-7-an adenocarcinoma cell line, A-549-a human lung cancer cell line, HCT-116-a human colon adenocarcinoma.

Table 5: The minimum inhibitory concentration (MICs) (mg/ml) of Capparis cartilaginea extracts

\begin{tabular}{llll}
\hline Plant sample & S. aureus & E. coli & P. aeruginosa \\
\hline Leaves & $5 \pm 0.0$ & $>5 \pm 0.0$ & $>5 \pm 0.0$ \\
Twig & $>5 \pm 0.0$ & $>5 \pm 0.0$ & $>5 \pm 0.0$ \\
Stem & $5 \pm 0.0$ & $>5 \pm 0.0$ & $>5 \pm 0.0$ \\
Essential oil & $>5 \pm 0.0$ & $>5 \pm 0.0$ & $>5 \pm 0.0$ \\
Ceftriaxon & nd & $<0.15 \pm 0.0$ & $<0.15 \pm 0.0$ \\
Amikacin & $<0.15 \pm 0.0$ & nd & nd \\
\hline
\end{tabular}

Values of inhibition zone are obtained as mean \pm SD. Each value is the mean of three triplicate. S. aureus-Staphylococcus aureus, E. coli-Esherichia coli, P. Erogenous-Pseudomonas aeruginosa. nd-not determined.

\section{The cytotoxic activity}

The results showed that the twigs extract possessed the highest cytotoxic activity against A-549 cell line with an $\mathrm{IC}_{50}$ of $57.5 \mu \mathrm{g} / \mathrm{ml}$, followed by the stem extract ( $\mathrm{IC}_{50}$ of $240 \mu \mathrm{g} / \mathrm{ml}$ ) (table 4 ).

\section{The antibacterial activity}

The leaves and stem extracts showed weak antibacterial activity against $S$. aureus with MIC values of $5.0 \mathrm{mg} / \mathrm{ml}$, whereas other extracts of different parts as well as essential oil of $C$. cartilaginea showed no activity against $E$. coli and $P$. aeruginosa (table 5).

\section{DISCUSSION}

In this study, the phytochemical screening of various parts of $C$. cartilaginea as well as the biological activities of leaves extracts, including antibacterial, antioxidant, cytotoxicity, acute toxicity and anti-inflammatory activities were evaluated. Phytochemical results indicated the presence of alkaloids, carbohydrates, protein, coumarin, phytosterols, bitter principles, phenols and tannins and the absence of saponins and anthraglycosides in the $C$. cartilaginea extracts. This study is in agreement with a recent study carried out in Abyan, Yemen [10] except that alkaloids were absent and saponins were found in the leaves extract in their study. These differences may be ascribed to the environmental factors, such as altitude, temperature, illumination, precipitation, humidity, soils and locations [33].

Our findings show that isothiocyanates, including isopropyl isothiocyanate, butane, 1-isothiocyanate and isobutyl isothiocyanate, represented $99.64 \%$ of the essential oil of $C$. cartilaginea leaves. A previous study has isolated isothiocyanate components from the leaves of $C$. cartilaginea which is obtained from Egypt [3]. In fact, isothiocyanate compounds found to be common in $C$. cartilaginea as other species of Capparis [3, 32]. In addition, the essential oil of $C$. cartilaginea showed weak antibacterial and antioxidant activities. These results could be responsible for the antagonistic effects of other compounds or the presence of other nonactive compounds [34]. Volatile sulfur-containing compounds, such as isothiocyanate have showed antioxidant, cytotoxic effects and apoptosis induction [35] and cancer chemoprevention properties [36, 37]. Individual components of the essential oil need to be further investigated for their biological activities.

Notably, the leaves extract of $C$. cartilaginea did not show toxicological or behavioral changes in the rats even at the highest dose used (5000 $\mathrm{mg} / \mathrm{kg}$ ). Doses of 200 and $400 \mathrm{mg} / \mathrm{kg}$ were selected in this study to determine the anti-inflammatory effect of the plant. The antiinflammatory effect of leaves extracts was assessed using the formalin-induced inflammation method (2\%). Formalin has been used as an inflammatory inducer to evaluate the anti-inflammatory effect of plant extracts in several previous investigations $[24,38,39]$. Intraplantar formalin injection in rats produces a biphasic response where the neurogenic pain is induced in the first phase, while inflammatory processes are induced in the second phase [40]. Various mediators are produced in inflammation, including prostaglandins, serotonin, histamine, bradykinin and cytokines [41]. Interestingly, the leaves extract showed significant inhibition of edema during the second phase of the edema process. The anti-inflammatory effect of the extract was not significantly different from that of diclofenac, a 
prostaglandin synthesis inhibitor, indicating a possible similar action. However, the mechanism of anti-inflammatory action of $C$. cartilaginea needs to be elucidated. The presence of alkaloids, flavonoids, coumarins, phenolic and tannin compounds in the leaves extract may contribute to its anti-inflammatory activity [42].

The extracts of $C$. cartilaginea showed antioxidant activity which was in agreement with previous studies $[9,10]$. Plant phenolic compounds of secondary metabolites, such as simple phenolics, phenylpropanoids, coumarins, lignans, quinones, tannins and flavonoids are known as antioxidants $[43,44]$. It is well known that free radicals contribute to various human disorders, such as atherosclerosis, arthritis, gastritis and cancer [45] which play an important role in the pathogenesis of inflammation as well [46]. Therefore, $C$. cartilaginea leaves could have a role in preventing these disorders due to their antioxidant activity.

In the present study, the extract of twigs showed high cytotoxic activity against lung cell lines (A-549) followed by the stem extract. However, a previous study has reported no cytotoxic effect $(>50$ $\mu \mathrm{g} / \mathrm{ml}$ ) of leaves extract of $C$. cartilaginea on lung (A-427), urinary bladder (5637) and breast (MCF-7) cell lines [9]. Another study has also reported that the methanol extract of a flowering branch of the species exhibited no cytotoxic effect $(>50 \mu \mathrm{g} / \mathrm{ml}$ ) against cancer cells of MCF-7, human hepatocellular carcinoma (HepG-2), mouse fibrosarcoma (WEHI-164), A549 and Madin-Darby bovine kidney (MDBK) $[14,38]$. These contradictory findings may be due to the fact that in the current study, the lowest $\mathrm{IC}_{50}$ value was $57.5 \mu \mathrm{g} / \mathrm{ml}$ while in the previous studies, $50 \mu \mathrm{g} / \mathrm{ml}$ was used as a maximum concentration.

The current study leaves and twigs extracts showed weak antibacterial activity against $S$. aureus and no effect against $E$. coli and $P$. aeruginosa. These results were in consistence with those reported by Mothana et al. [9]. However, a recent study indicated that the extract of the aerial parts of $C$. cartilaginea showed antibacterial activity against $S$. aureus, E. coli and $P$. aeruginosa with MIC values of $13.69,62.5$ and $52.08 \mu \mathrm{g} / \mathrm{ml}$, respectively [17]. Quantity and quality of chemical components of plants may be responsible for the different activities of the plant extracts [47].

\section{CONCLUSION}

Three isothiocyanates, isopropyl isothiocyanate, butane,1isothiocyanate and isobutyl isothiocyanate, represented the major components of the essential oil of $C$. cartilaginea leaves. The methanol leaves extract of $C$. cartilaginea has been shown to have antioxidant effects and significant anti-inflammatory effect without causing toxicity upon oral administration. Therefore, the leaves extract is a potential source of bioactive compounds that could have a role in anti-inflammation. The twigs extract of the species also possesses a potential cytotoxic effect on human lung cell line suggesting the presence of selective cytotoxic compounds.

\section{ACKNOWLEDGEMENT}

The authors would like to acknowledge the Microbiology Department of Yemen Lab, Sana`a Yemen; Faculty of Pharmacy, Sana'a University, Yemen; Cell Culture Lab Department of Pharmacology and Toxicology, Faculty of Pharmacy, Al-Azhar University-Nasr City-Cario, Egypt, for the laboratory facilities.

\section{AUTHORS CONTRIBUTIONS}

Dr. Bushra Abdulkarim Moharram and Dr. Hassan M. AL-Mahbashi conceived, designed and performed the experiments.

Faten Ali Aqlan helped in the experiment part.

Dr. Bushra Abdulkarim Moharram and Dr. Riyadh Saifali analyzed the data and wrote the paper. All authors read and approved the final manuscript.

\section{CONFLICT OF INTERESTS}

The authors declare that they have no conflicts of interests.

\section{REFERENCES}

1. Inocencio C, Rivera D, Obón MC, Alcaraz F, Barreña JA. A systematic revision of Capparis section Capparis (Capparaceae) 1, 2. Ann Mo Bot Gard 2006;93:122-49.
2. Al-Khulaidi A. Flora of Yemen. Sustainable natural resource management project (SNRMP) II. Sana'a, Yemen: Obaidi Publishing; 2013.

3. Hamed AR, Abdel-Shafeek KA, Abdel-Azim NS, Ismail SI, Hammouda FM. Chemical investigation of some Capparis species growing in Egypt and their antioxidant activity. Evid Based Complement Alternat Med 2007;4 Suppl 1:25-8.

4. Lansky EP, Paavilainen HM, Lansky S. Caper: the genus Capparis. Boca Raton, FL: CRC Press; 2013.

5. Miller AG, Morris M. Plants of dhofar: the southern region of oman, traditional, economic and medicinal uses. sultanate of oman: the office of the adviser for the conservation of the environment, diwan of royal court; 1988.

6. Al-Dubai A, Al-Khulaidi A. Medicinal and aromatic plants of Yemen (In Arabic). Sana'a, Yemen: Obadi Center for Studies and Publishing; 1996.

7. Hehmeyer I, Schönig H. Herbal medicine in yemen: traditional knowledge and practice, and their value for today's world. Leiden, the Netherlands: Brill; 2012.

8. Sharaf M, El-Ansari MA, Saleh NA. Flavonoids of four Cleome and three Capparis species. Biochem Syst Ecol 1997;25:161-6.

9. Mothana RA, Lindequist U, Gruenert R, Bednarski PJ. Studies of the in vitro anticancer, antimicrobial and antioxidant potentials of selected Yemeni medicinal plants from the island Soqotra. BMC Complement Altern Med 2009;9:7.

10. Galib NA, Algfri SK. Phytochemical screening and antioxidant evaluation by DPPH of Capparis cartilaginea decne leaves. J Med Plants 2016;4:280-6.

11. Ageel A, Parmar N, Mossa J, Al-Yahya M, Al-Said M, Tariq M. Anti-inflammatory activity of some Saudi Arabian medicinal plants. Agents Actions 1986;17:383-4.

12. El Azhary K, Jouti NT, El Khachibi M, Moutia M, Tabyaoui I, El Hou A, et al. Anti-inflammatory potential of Capparis spinosa L. in vivo in mice through inhibition of cell infiltration and cytokine gene expression. BMC Complement Altern Med 2017;17:81.

13. Chen JJ, Kuo WL, Liao HR, Kuo YH, Chen IS, Shu CW, et al. A new benzenoid and anti-inflammatory constituent of Capparis acutifolia. Chem Nat Compd 2017;53:21-3.

14. Esmaeili S, Hamzeloo Moghadam M, Ghaffari S, Mosaddegh M. Cytotoxic activity screening of some medicinal plants from south of Iran. Res J Pharmacogn 2014;1:19-25.

15. Latif A, Amer HM, Hamad ME, Alarifi SAR, Almajhdi FN. Medicinal plants from Saudi Arabia and Indonesia: In vitro cytotoxicity evaluation on Vero and HEp-2 cells. J Med Plants Res 2014;8:1065-73.

16. Abutaha N, Al-Mekhlafi A. Evaluation of the safe use of the larvicidal fraction of Capparis cartilaginea Decne. against Aedes caspius (Pallas) (Diptera: Culicidae) larvae. Afr Entomol 2014;22:838-46.

17. Rahimifard N, Shojaii A, Mahbobi M, Hafezan G, Bagheri F, Asgarpanah J. Evaluation of antibacterial activity and flavonoid content of two Capparis species from Iran. J Med Plants 2015;3:89-94.

18. Alasbahi R, Safiyeva S, Craker L. Antimicrobial activity of some Yemeni medicinal plants. J Herbs Spices Med Plants 1999;6:75-83.

19. Gilani AUH, Aftab K. Hypotensive and spasmolytic activities of ethanolic extract of Capparis cartilaginea. Phytother Res 1994;8:145-8.

20. Banu KS, Cathrine L. General techniques involved in the phytochemical analysis. Int J Adv Res Computer Sci 2015;2:25-32.

21. Wagner $\mathrm{H}$, Bladt S. Plant drug analysis: a thin layer chromatography atlas. New York: Springer Science and Business Media; 1996.

22. Adams RP. Identification of essential oil components by gas chromatography/mass spectrometry. $4^{\text {th }}$ ed. Illinois USA: Allured Publishing Corporation; 2007.

23. Al-Mahbashi HM, El-Shaibany A, Saad FA. Evaluation of acute toxicity and antimicrobial effects of the bark extract of Bisham (Commiphora gileadensis L.). J Chem Pharm Res 2015;7:810-4.

24. Hosseinzadeh $\mathrm{H}$, Younesi HM. Antinociceptive and antiinflammatory effects of Crocus sativus L. stigma and petal extracts in mice. BMC Pharmacol 2002;2:7.

25. Shripad B, Abhijeet A, Inayat P, Nema N. Analgesic and antiinflammatory evaluation of Ficus microcarpa l. leaves extract. Asian J Pharm Clin Res 2012;5:258-61. 
26. Blois MS. Antioxidant determinations by the use of a stable free radical. Nature 1958;181:1199-200.

27. Bains A, Tripathi A. Evaluation of antioxidant and antiinflammatory properties of aqueous extract of wild mushrooms collected from Himachal Pradesh. Asian J Pharm Clin Res 2017;10:467-72.

28. Mosmann T. Rapid colorimetric assay for cellular growth and survival: application to proliferation and cytotoxicity assays. J Immunol Methods 1983;65:55-63.

29. Scudiero DA, Shoemaker RH, Paull KD, Monks A, Tierney S, Nofziger $\mathrm{TH}$, et al. Evaluation of a soluble tetrazolium/ formazan assay for cell growth and drug sensitivity in culture using human and other tumor cell lines. Cancer Res 1988;48:4827-33.

30. Coyle MB. Manual of antimicrobial susceptibility testing. Washington D. C.: American Society for Microbiology; 2005.

31. Jantan Ib, Karim Moharam BA, Santhanam J, Jamal JA. Correlation between chemical composition and antifungal activity of the essential oils of eight Cinnamomum species. Pharm Biol 2008;46:406-12.

32. Afsharypuor S, Jazy AA. Stachydrine and volatile isothiocyanates from the unripe fruit of Capparis spinosa L. DARU 1999; 7:11-3.

33. Zidorn C, Stuppner H. Evaluation of chemosystematic characters in the genus Leontodon (Asteraceae). Taxon 2001;50:115-33.

34. Ogunlaja 00, Moodley R, Baijnath H, Jonnalagadda SB. Chemical constituents and in vitro antioxidant activity of crude extracts and compounds from leaves and stem bark of Ficus burtt-Davyi. Acta Pol Pharm 2016;73:1593-600.

35. Wu X, Kassie F, Mersch-Sundermann V. Induction of apoptosis in tumor cells by naturally occurring sulfur-containing compounds. Mutat Res 2005;589:81-102.

36. Bianchini $F$, Vainio $H$. Isothiocyanates in cancer prevention. Drug Metab Rev 2004;36:655-67.
37. Zhang Y. Cancer-preventive isothiocyanates: measurement of human exposure and mechanism of action. Mutat Res 2004;555:173-90.

38. Igbe I, Ching FP, Eromon A. Anti-inflammatory activity of aqueous fruit pulp extract of Hunteria umbellata K. schum in acute and chronic inflammation. Acta Pol Pharm Drug Res 2010;67:81-5.

39. Safari V, Ngugi M, Orinda G, Njagi E. Anti-pyretic, antiinflammatory and analgesic activities of aqueous leaf extract of Urtica dioica L. in albino mice. Med Aromat Plants 2016;5:1-7.

40. Fu KY, Light AR, Maixner W. Long-lasting inflammation and long-term hyperalgesia after subcutaneous formalin injection into the rat hind paw. J Pain 2001;2:2-11.

41. Damas J, Liegeois JF. The inflammatory reaction induced by formalin in the rat paw. Naunyn Schmiedeberg's Arch Pharmacol 1999;359:220-7.

42. Perez G. Anti-inflammatory activity of compounds isolated from plants. Sci World J 2001;1:713-84.

43. Jedinak A, Farago J, Psenakova I, Maliar T. Approaches to flavonoid production in plant tissue cultures. Biologia (Bratisl) 2004;59:697-710.

44. Dasgupta A, Rai M, Acharya K. Phytochemical analysis and in vitro antioxidant activity of a wild edible mushroom Entoloma lividoalbum. Phytochem Anal 2015;8:171-4.

45. Hela A, Abdullah A. Antioxidant and antimicrobial activities of methanol extracts of some Verbena species: in vitro evaluation of antioxidant and antimicrobial activity in relation to polyphenolic content. J Appl Sci Res 2010;6:683-9.

46. Winrow V, Winyard P, Morris C, Blake D. Free radicals in inflammation: second messengers and mediators of tissue destruction. Br Med Bull 1993;49:506-22.

47. Paiva P, Gomes F, Napoleão T, Sa R, Correia M, Coelho L. Antimicrobial activity of secondary metabolites and lectins from plants. In: Mendez Vilas A. editor. Current research, technology and education topics in applied microbiology and microbial biotechnology. Brazil: Formatex; 2010. p. 396-406. 